\title{
Mechanic killed pouring gasoline on fire
}

\section{SUMMARY \\ On January 9, 2006, a 37-year-old field mechanic for a logging company was killed when he tried to stoke a warming} fire by pouring gasoline on it. The mechanic and a coworker arrived at a logging site at 7 a.m. to perform maintenance on a log-loading machine. The weather was cold and rainy, and the coworker started a warming fire, using a combination of diesel fuel and chainsaw gasoline. About 8 a.m., the

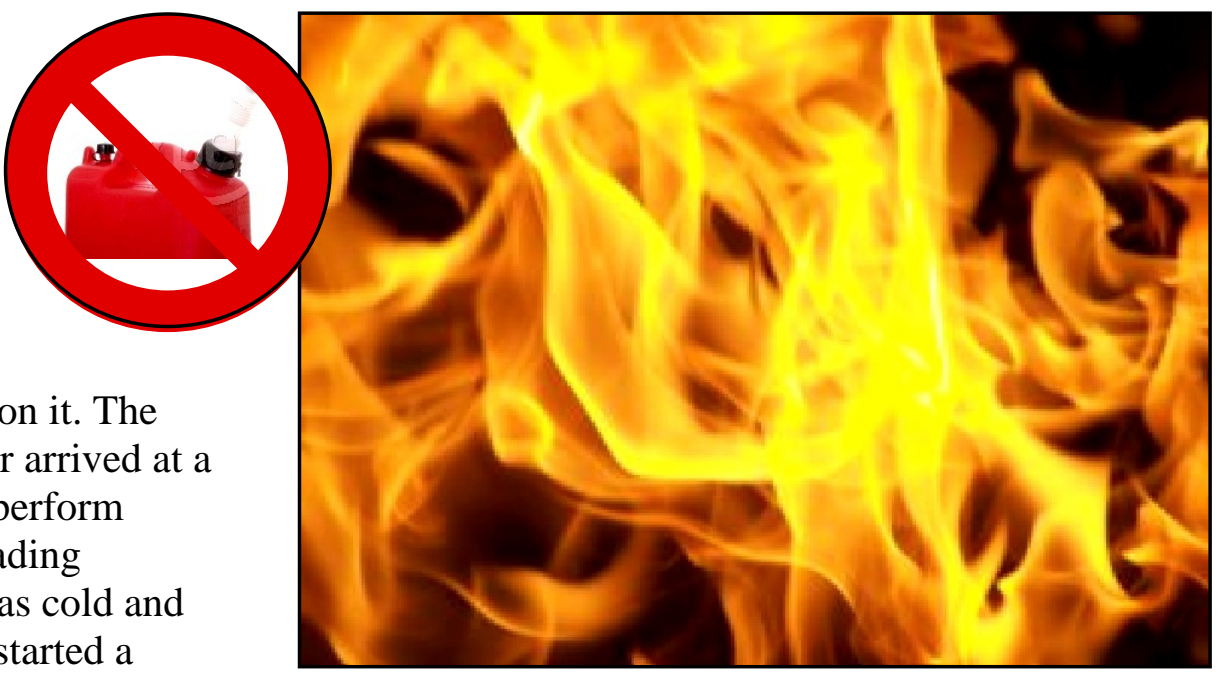

Pouring chainsaw gas on a fire from a 5-gallon plastic container caused the container to explode in a deadly fireball. coworker left to call for parts on a cell phone. He returned about 15 minutes later and found the mechanic lying 35 feet from the warming fire, engulfed in flames. Another fire, about 20 feet from the warming fire, was found to be caused by a burning 5-gallon plastic gasoline container. The victim was pronounced dead at the scene.

\section{CAUSE OF DEATH: Severe thermal injuries}

\section{RECOMMENDATIONS}

- Never use gasoline or saw gas near an open flame.

- Loggers should use appropriate materials to safely start and stoke a fire.

- Employers must train employees on safe procedures for starting and stoking fires, and should emphasize the extreme hazard of using gasoline on a fire. 


\section{INTRODUCTION}

On January 9, 2006, a 37-year-old field mechanic for a logging company was killed when he tried to stoke a warming fire by pouring gasoline on it. OR-FACE was notified by OR-OSHA the same day. This report is based on information from OR-OSHA and medical examiner reports.

The employer has operated in Oregon for 50 years in logging activities, and is now one of Oregon's largest logging companies. Heavy construction and highway work were added in the 1970s. The company now employs 100-140 workers on multiple projects, split about evenly between logging and construction work.

The employer had a thorough safety and health program for employees that included documented training, field supervision, and investigation of injuries. The field mechanic in this incident had worked for the company for 10 years. He received training in basic safety and health policy orientation, lockout/tagout, fire training, hazard communication, personal protective equipment, and first aid; and was informed on specific job duties and responsibilities, and OR-OSHA compliance. He was known as a safe and conscientious worker.

No formal company policies or training covered the practice of building warming fires, but interviews with supervisors and employees indicated a general awareness that gasoline by itself was not to be used, and only a mixture of diesel and gasoline was appropriate for initial ignition of a fire. Boosting a fire with gasoline was generally recognized as an unsafe practice. The field mechanic in this incident had never been observed using straight gasoline on a fire.

\section{INVESTIGATION}

On January 9, 2006, a 37-year-old field mechanic and a coworker arrived at a logging site at 7 a.m. to perform maintenance on a log-loading machine. The weather was cold and rainy, and the coworker started a warming fire, using a combination of diesel fuel and chainsaw gasoline. About 8 a.m., the coworker left to call for parts on a cell phone. He returned about 15 minutes later and found the mechanic lying 35 feet from the warming fire, engulfed in flames. Another fire, about 20 feet from the warming fire, was found to be caused by a burning 5-gallon plastic gasoline container. The container had about one-half gallon of chainsaw gasoline inside it prior to the explosion. A separate 1-gallon container with diesel fuel was not used by the victim. Apparently, the mechanic poured the gasoline mixture straight from the 5-gallon container onto the smoldering warming fire. He was killed in the resulting explosion.

\section{RECOMMENDATIONSIDISCUSSION}

\section{Recommendation \#1. Never use gasoline or saw gas near an open flame.}

This incident emphasizes that experienced workers who know the dangers of using gasoline near an open flame may still be tempted to violate this cardinal rule. Considerable confusion exists in the logging industry on how to regulate the use of gasoline for building fires for slash piles or personal warming fires. The one certain rule is that gasoline or saw gas should never be used near a fire that is already going. Heat rapidly vaporizes the flammable liquid and makes an 
explosion very likely. Also, if gasoline is poured on an existing fire, as in this incident, a flame can travel up the stream of gasoline into the container and explode. Requirements vary on the safe distance for using flammable liquids around an open flame or other source of ignition: from no less than 10 feet away for refueling a chainsaw (CFR 1910.266(e)(2)(iv)), to 35 feet away when refueling a vehicle (OAR 437-007-0580 in Oregon), to 50 feet away for general use (CFR 1926.152(f)(3)). Everywhere, flammable liquids must be stored in approved, labeled containers.

\section{Recommendation \#2. Loggers should use appropriate materials to safely start and stoke a fire.}

No Oregon OSHA forest rules relate to the practice of building a warming fire. A federal OSHA standard states: "Flammable and combustible liquids, including chainsaw and diesel fuel may be used to start a fire, provided the employer assures that in the particular situation its use does not create a hazard for an employee” (29 CFR 1910.266(d)(9)(iv)). The rule originally stated that flammable liquids were not permitted to start a fire but objections from loggers lead to a discretionary policy by the employer.

An authorized use of flammable liquids to start a fire in the woods involves a mixture of gasoline and diesel fuel, which are both commonly available at logging sites. Standards for drip-torch fuel developed by the U.S. Bureau of Land Management and U.S. Forest Service for woodland firefighters specify a ratio of 3:1 or 4:1 diesel to gasoline. The higher proportion of diesel fuel inhibits the explosive potential of the gasoline. Diesel fuel alone can be safely used to start a fire, but in wet conditions the diesel may burn off and fail to ignite the wood. Thus, a mixture was developed to include gasoline. The warming fire in this incident was initially started with a mixture of diesel and gasoline.

Caution is still necessary with a diesel-gasoline mixture. First, a specially designated, approved, and labeled safety can must be used to mix the fuel (OAR 437-007-0580). The fuel mixture can then be used to start a fire. The only safe way to use the fuel mixture on a fire that is already going is through an authorized drip torch, which dispenses the fuel in a regulated flow and prevents a flame from traveling up the fuel stream into the container. Even with a drip torch, caution is necessary to avoid splashing fuel and setting yourself on fire.

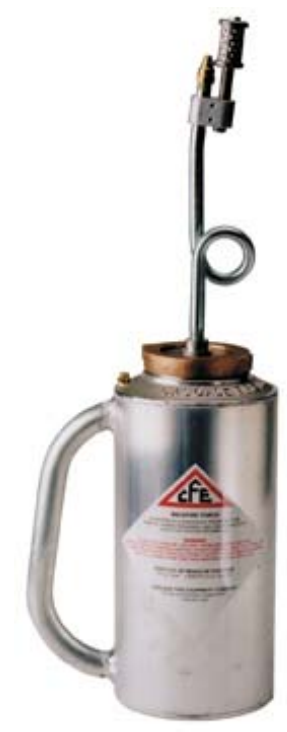

The only approved method for using liquid fuel to start or stoke a fire involves use of a drip-torch, with a mixture of diesel fuel and gasoline (ratio $3: 1$ or $4: 1$ ).

Fallers or other loggers in a remote location may not have access to diesel fuel and may be tempted to use saw gas alone to start a fire. Federal OSHA makes the following comment on the use of saw gas to start a fire.

[W] hen an area is cold and wet, gasoline will not volatilize or burn rapidly. However, as the fire gains intensity, the gasoline will evaporate more rapidly, causing the fire to suddenly flame up and can rapidly get out of control. Instead of using gasoline or a gasoline mixture, there are products available that are not combustible to start fires, such 
as fire starters comprised of sawdust and wax. These products are small, light weight and will not suddenly accelerate their combustion.

The described condition indicates the explosive potential of gasoline used to start a warming fire, depending on the degree of ventilation to diffuse vapors. Fallers should consider carrying fire sticks with their equipment on those occasions when a warming fire may be wanted.

Warming fires are common in logging operations, especially during winter months, and cannot be prohibited. The use of engine fuels to help start or stoke a fire remains controversial. The states of Oregon and Washington follow the federal OSHA standard to permit the use of liquid fuels under "safe" conditions, subject to interpretation. California prohibited the use of any engine fuel to start a fire in logging operations (Title 8, Sec. 6283(m)(7)), but made an exception in 2000 for diesel fuel as recommended by Associated California Loggers. A hazard alert for warming fires by Associated Oregon Loggers recommends: Do not use gasoline or saw gas to start or revive a fire - and then refers to the approved use of drip-torch fuel, composed of three parts diesel to one part gasoline.

This incident demonstrates the extreme hazard of using gasoline or saw gas on a fire. Even starting a fire involves bringing an open flame near the fuel, which creates an extreme hazard if saw gas alone is used. Loggers may safely use a 3:1 or 4:1 mixture of diesel to gasoline with appropriate equipment and training in safe practices. As an alternative to avoid the use of any liquid fuels, loggers should consider the use of waterproof fire sticks or solid fuel gel to start and stoke warming fires. Adding this equipment to standard logging supplies would involve very little burden.

\section{Recommendation \#3. Employers must train employees on safe procedures for starting and stoking fires, and should emphasize the extreme hazard of using gasoline on a fire.}

Most people know the danger of using gasoline around a fire, but cases of fatalities and severe injuries from gasoline near fires, especially with burn barrels, continue to occur. This incident emphasizes the continuing need for employers to explicitly train workers on the extreme hazard of gasoline near any source of ignition. Employers should train workers in proper procedures to start and maintain a fire without the use of gasoline. Necessary equipment should be provided.

Safety recommendations for warming fires by the Association of Oregon Loggers and the Forest Resources Association include the following points.

- Clear an adequate firebreak around warming fires or contain in a burn barrel.

- $\quad$ Never use gasoline or any liquid fuel to stoke an existing fire.

- $\quad$ Keep fires small.

- Keep a fire extinguisher and fire-suppression tools readily accessible at any warming fire.

- Keep chainsaws and saw fuel at least 10 feet from any open flame or other source of ignition.

- Do not engage in horseplay around a fire.

- If your clothing catches on fire, remember to “stop, drop, and roll.” Do not run. Cover your face with your hands and roll on the ground until all flames are extinguished. 


\section{REFERENCES}

Boulder Mountain Fire Protection District. How to use a drip torch. Available online: www.bouldermountainfire.org/training/drip/page1.html

Forest Resources Association. (2006). Warming fire burns logging company employee. Available online: www.forestresources.org/app/bulletin_pdfs/06s3_2.pdf

Forest Resources Association. (2003). Warming fire gets out of control. Available online: www.loggingsafety.com/app/index.php?r=safety_alert\&a=view\&i=217

California OSHA Standards Board. (2001). Amendments to the logging and sawmill safety orders with regard to logging operations. Available online:

www.dir.ca.gov/oshsb/loggingoperfsoraddend.pdf

Oregon OSHA. Flammable and combustible liquids. Online resource:

www.cbs.state.or.us/osha/subjects/flammable_and_combustible_liquids.html

U.S. Bureau of Land Management \& U.S. Forest Service. (2007). Interagency standards for fire and fire aviation operations. Available online: www.nifc.gov/red_book/

U.S. OSHA. OSHA Logging Preamble: Section V: Summary and Explanation of the Final Standard: Par.(d) General Requirements: Flammable and Combustible Liquids. Available online: www.osha.gov/SLTC/etools/logging/sections/preamble/flammable_preamble.html

\section{FOR MORE INFORMATION}

OR-FACE/CROET L606

Oregon Health \& Science University

3181 SW Sam Jackson Park Rd

Portland OR 97239-3098

Phone 503-494-2281

Email: orface@ohsu.edu

Website: www.ohsu.edu/croet/face/

Oregon Fatality Assessment and Control Evaluation (OR-FACE) is a project of the Center for Research on Occupational and Environmental Toxicology (CROET) at Oregon Health \& Science University (OHSU). OR-FACE is supported by a cooperative agreement with the National Institute for Occupational Safety and Health (NIOSH), Division of Safety Research (U60/OH008324), through the Oregon Worker IIIness and Injury Prevention Program (OWIIPP), Oregon Public Health Division.

OR-FACE reports are for information, research, or occupational injury control only. Safety and health practices may have changed since the investigation was conducted and the report was completed. Persons needing regulatory compliance information should consult the appropriate regulatory agency. 